\title{
Miejsce samorealizacji w systemie preferowanych wartości w szkole w opiniach nauczycieli szkół dla mniejszości i większości ze środowisk wielokulturowych krajów Grupy Wyszehradzkiej
}

\begin{abstract}
Streszczenie: W artykule podjęty został temat samorealizacji w systemach preferowanych wartości w szkołach w środowiskach wielokulturowych. Wskazanie samorealizacji jako wartości wynikającej z obowiązujących w naszej cywilizacji zasad automatycznie przesądza o jej wartości w hierarchiach wartości w szkole.

Wskazane zostały te systemy porównawczo w sąsiednich szkołach dla mniejszości i dla większości ze środowisk wielokulturowych z mniejszością autochtoniczną: niemiecką w Polsce; polską w Republice Czeskiej; węgierską na Słowacji; słowacką na Węgrzech. Wyniki badań wskazują, że wyróżnione wartości różnią się w zależności od państwa czy typu szkoły (mniejszości vs większości), jednak samorealizacja we wszystkich państwach i typach szkół zajmuje niechlubne ostatnie miejsca.
\end{abstract}

Słowa kluczowe: samorealizacja, system wartości, szkoła na pograniczach

\section{Wprowadzenie: samorealizacja jako wartość}

W obszarze naszej cywilizacji obowiązuje zasada, że „wartości świata należy odliczać, zaczynając od jednostki ludzkiej" (Obuchowski, 1993, s. 9), zatem zasada podmiotowego standardu ewaluacji (Obuchowski, 1993, s. 9) ${ }^{1}$ : siebie jako źródła swego postępowania; celów jako przedmiotu swoich intencji; świata jako szansy swoich możliwości. Oznacza to, że standardem jest przygotowanie ucznia do podmiotowości rozumianej jako „podmiot decyzyjny” (Poleszczuk, 2002, s. 15). A postulat ten i wymieniona zasada formułują zadania szkoły jako przygotowanie uczniów do samorealizacji. Bowiem właśnie

1 Szersze omówienie w kontekście wprowadzenia do problematyki komunikacji z Innym w środowiskach wielokulturowych zobacz w pracy Katarzyny Olbrycht (Olbrycht, 2003). 
w typowych "humanistycznych” ujęciach pojęcie Ja, jak ujmuje to Tadeusz Lewowicki, bywa traktowane jako symbol samookreślenia i samorealizacji (Lewowicki, 1993, s. 596). Zaś zadanie pedagogów w stosunku do uczniów definiuje Tadeusz Kotarbiński analogicznie do zadań etyki: „etyka usiłuje wskazać działania, pedagogika natomiast pragnie wytyczyć drogi kształtowania dyspozycji do działań" (Kotarbiński, 1993, s. 199).

Samorealizacja jest zatem wartością niewątpliwie zobowiązującą do podejmowania oddziaływań pedagogicznych, a zadania szkoły w kontekście wymienionych zasad i postulatu są jasno wytyczone - zobowiązują do odkrywania i wspomagania sposobów samorealizacji, pozwalającej przede wszystkim na traktowanie „świata jako szansy swoich możliwości”. Zadania te jednak są wielorako uwarunkowane, m.in. przynależnością do etnikum: „Zaraz na początku należy wyjaśnić ewentualne niejasności co do związku stylu życia z planowaniem życia. Podziały klasowe i inne fundamentalne linie podziałów społecznych, jak te związane z płcią i etnicznością, można częściowo zdefiniować w kategoriach nierównego dostępu do różnych form samorealizacji i uzyskiwania nowych podstaw działania" (Giddens, 2001, s. 9).

Wskazanie w niniejszym artykule miejsca samorealizacji w hierarchii preferowanych wartości szkoły w ramach środowisk wielokulturowych z mniejszością autochtoniczną sprawy te problematyzuje o spojrzenie uwzględniające możliwe różne ich ujęcia w sąsiadujących szkołach dla mniejszości i większości. Można tak domniemywać ze względu na możliwe różne określanie przez młodzież swoich możliwości i intencji wskazujących oczekiwaną jakość życia (Urban, 2014a), a zatem możliwość wykorzystania szans życiowych $^{2}$. Pojawia się w tym kontekście pytanie, jak szkoła pogranicza pojmuje i wspomaga wykorzystywanie szans przez młodzież; w szczególności chodzi o szanse wynikające z dorastania w wielokulturowym środowisku.

Podjęte rozważania są częścią problematyki dotyczącej systemu preferowanych wartości szkoły i poszerzoną interpretacją - teoretycznym osadzeniem tematu - rozważań dotyczących miejsca samorealizacji ${ }^{3}$. Temat tożsamości młodzieży ujęty z punktu widzenia wyżej wymienionych kryteriów

2 Te „Weberowskie pojęcia łącznie - szans życiowych i apropriacji (zawłaszczania przez pewne grupy) - w nowych ujęciach" pojawiają się nawet w najnowszych wskaźnikach tak jak stare, a nawet są spotęgowane (Baranowski, 2009, s. 136).

3 Artykuł jest zwartą i poszerzoną wersją opracowania pojęcia samorealizacji jako wartości, które w rozproszonym ujęciu znajduje się w autorskiej rozprawie (Urban, 2014a), natomiast prezentowane tu wyniki badań dotyczą innego okresu. 
- dyspozycji do działań w kontekście samorealizacji (kreatywnie i zgodnie z własnymi intencjami), określania swojej szansy w świecie i wizji tego świata - jest rozwijany w tym artykule ze względu na przynależność do mniejszości narodowych vs większości, w konsekwencji „bycie absolwentem” szkoły dla mniejszości vs szkoły dla większości ${ }^{4}$. Zatem pytanie brzmi: Jak szkoły pogranicza pojmują swe zadanie kształtowania uniwersalnych wartości w kontekście wielokulturowości?

Zaprezentowanie w niniejszym artykule systemów realizowanych wartości szkoły w opiniach nauczycieli szkół dla mniejszości i większości ze środowisk wielokulturowych krajów Grupy Wyszehradzkiej sytuuje się we wskazanej konwencji oczekiwań roli szkoły w przygotowaniu do wyboru wartości w demokracji. Wskazanie w dalszym ciągu realizowanych hierarchii wartości szkół ujawnia zależności tych wyborów od typu szkoły i jej rodzajus. W niniejszym artykule zwrócono uwagę w szczególności na „niechlubne” miejsce „samorealizacji” w tych hierarchiach.

4 Badanie postaw ze względu na przynależność do mniejszości narodowych napotyka niewątpliwie trudności wskazane przez Jerzego Szackiego w badaniach narodu, a jednym z podanych przez autora rozwiązań jest odwołanie się do instytucjonalizacji (w niniejszej pracy - „szkoły”) (Szacki, 2004, s. 56).

5 „Szkoła” - chodzi o licea dla mniejszości i dla większości w środowiskach $\mathrm{z}$ mniejszością autochtoniczną - $\mathrm{w}$ niniejszym artykule występuje tu $\mathrm{w}$ dwu znaczeniach. Po pierwsze - opisywana jako „typ szkoły” („szkoła” określana jest ze względu na umiejscowienie w państwie). W tym znaczeniu „typ szkoły” - zarówno dla mniejszości, jak i większości - pokazuje ją jako szkołę danego państwa. Po drugie - opisywana jako „rodzaj szkoły” - „szkoła” określana jest ze względu na szkołę dla mniejszości vs szkołę dla większości w danym środowisku. W badaniach - przeprowadzonych w 2011 i 2013 roku w środowiskach z mniejszością autochtoniczną - wyróżnione zostały szkoły dla grup mniejszości i szkoły dla współżyjących z nimi większości grup odniesienia porównawczego. Hierarchie (wyznaczone jako obowiązujące dla roku 2010) to oceny nauczycieli liceów ogólnokształcących dla mniejszości narodowych („licea dla mniejszości” w Polsce w artykule oznaczają licea z klasami dla mniejszości - w czasie badań brak było tego rodzaju szkół) i sąsiednich szkół dla większości (łącznie 568 nauczycieli) ze środowisk z mniejszością: niemiecką w Polsce; polską w Republice Czeskiej; węgierską na Słowacji; słowacką na Węgrzech. Dokładny opis konceptualizacji badań „szkoły” dotyczący ocen dla roku 2004 (przeprowadzonych tak samo i łącznie dla roku 2010), tj. wyróżnienia „typu” i „rodzaju” szkoły, ich doboru i doboru grup nauczycieli patrz w rozprawie J. Urban (Urban, 2014a, ss. 295, 307-319). 


\section{Standardy europejskie a myślenie o edukacji w UE}

Podstawą wyznaczania standardów europejskich jest aksjologia, którą ujawniły dyskusje towarzyszące pracom nad „Konstytucją dla Europy”, a która: „Zawiera zarówno wartości »iberalne «, wyrażone w wartości wolności, jak i wartości »komunitarystyczne« skonceptualizowane w wartość solidarności” (Bunikowski, 2006, s. 3). Pomimo że nie stanowiła wiążącego prawa i niewiadomy był jej los, dyskusje dotyczące jej postaci wnosiły nowe treści do aksjologii prawa konstytucyjnego Unii Europejskiej, określonej głównie przez Traktat z Maastricht (Bunikowski, 2006, s. 6). Wzmocnienie dyskutowanej aksjologii Konstytucji dla Europy stanowiła Karta Praw Podstawowych, której systematyka determinuje hierarchię wartości, we wskazywanej kolejności (Bunikowski, 2006, s. 3): godność, wolność, równość i solidarność. Kolejno zatem godność jako esencja humanizmu, wolność jako respektowanie idei liberalnych oraz gwarantujące tendencje integracji społecznej - równość i solidarność.

Umiejętność wyborów wartości przez młodzież przywoływana jest też jako przygotowanie do obywatelstwa w demokratycznym społeczeństwie: „Demokracja wymaga od absolwentów szkół nie tylko społecznej, ale także politycznej dojrzałości, toteż niezmiernie ważne jest przygotowywanie młodego pokolenia do odpowiedzialnego wyboru wartości i podejmowania zgodnie z nimi decyzji" (Śliwerski, 2013, s. 18).

Należy jednak podkreślić, że nieobojętne jest rozumienie wartości, jej miejsce w hierarchii innych wartości oraz w jakim kontekście aksjologicznym jest umieszczona - jak pisze J. Mariański (Mariański, 2016) w kontekście "godności", jednak można przyjąć, że dotyczy to wszystkich wartości. Zatem nieobojętne są - jak będzie wskazane - sposób przekazu i umiejscowienie wartości w hierarchiach określanych przez szkołę.

Myślenie o edukacji w Unii Europejskiej jest wielotorowe - zauważa Michał Sitek (Sitek, 2009, s. 275) i wskazuje na możliwość wyróżnienia dwu podstawowych dyskursów edukacyjnych - symboliczny wspólnototwórczy (dawniejszy, lecz nadal silnie obecny) i nowszy, wiążący edukację i szkolenia z ideą jednolitego rynku: „Swoją obecność zaznaczył on już pod koniec lat 80., jednak przełomowe znaczenie dla jego wzmocnienia miało przyjęcie w 2000 roku tzw. strategii lizbońskiej, w której edukację i szkolenia uznano za podstawę budowania wzrostu gospodarczego oraz umacniania spójności społecznej. Główne miejsce w tym dyskursie zajmuje perspektywa uczenia się przez całe życie. (...) Podejście to stawia w centrum efekty uczenia się, 
czyli to, co uczący się wie, rozumie i co jest w stanie zrobić (w odróżnieniu od tradycyjnego skupiania uwagi na treściach kształcenia), a co tylko częściowo jest efektem szkolnictwa" (Sitek, 2009, s. 275).

\section{Tożsamość szkoły a hierarchie preferowanych wartości w szkole - spojrzenie nauczycieli'}

Wizja szkoły jest „bagażem” i „wizytówką” ucznia do przyszłego życia. Szkoła (Urban, 2014a, s. 122) jako instytucja edukacyjna kształtuje proces budowania własnej tożsamości ucznia i „posiadaną przez siebie pewną tożsamością wpisuje człowieka w życie społeczne i nadaje mu swoim autorytetem pewnej jakości jego własnej tożsamości (Nowak, 2009, s. 32)”. Zatem nieobojętna jest postać szkoły i jej przekaz. Szkoła odgrywa też decydującą rolę w alokacji jednostek w hierarchii społecznej (Domański, 2004, s. 201), a w trudnych warunkach pogranicza jej odpowiedzialność jest zwielokrotniona i tym większa, że w szkole na pograniczach zwielokrotnione są i trudniej uchwytne uwarunkowania.

Szkoła jest niebagatelnym wyznacznikiem postrzegania świata społecznego - poprzez własną wizję kształtującym możliwe jego rozumienia zarówno przez aktywność, jak i przez zaniechanie działań. Bowiem oswoić można różne postawy - powtórzmy: „zarówno to, co wspiera szkołę i uczące się w niej podmioty, jak i z dobrym skutkiem wszystko, co dla niej krzywdzące. (...) Oba ujęcia w praktyce szkoły znaczą jej tożsamość (Preuss-Kuchta, 2009, s. 19)". Szkoła może być ujmowana z różnych perspektyw ${ }^{7}$, a punktu widzenia wychowania młodzieży w społecznościach wielokulturowych ważne jest, jakie - w kontekście kształtowania tożsamości, w tym wykorzystywania szans życiowych - hierarchie wartości szkoła proponuje.

Hierarchie wartości w pracy szkoły wyznaczają nauczyciele, a te z kolei są wyznacznikiem planów życiowych młodzieży. Wartości są ważnymi regulatorami wyznaczającymi kształt życia społecznego, zatem uznawane przez ludzi hierarchie wartości, dążenia i plany życiowe stanowiły i stanowią przedmiot badań wielu nauk, a refleksja podejmowana przez filozofów ma najdłuższą tradycję

6 Dalszy ciąg artykułu to nieco zmieniona i uzupełniona część podrozdziału 6.3. (lecz w niniejszym artykule z uwzględnieniem wyników badań dla roku 2010) i częściowo 1.2.2 cytowanej rozprawy autorki (Urban, 2014a).

7 Bogusław Śliwerski wymienia perspektywę polityczną, prawną, filozoficzną, pedagogiczną, socjologiczną, wskazując jednocześnie potrzebę uwzględniania ich przenikania się (Śliwerski, 2013, s. 11). 
(Lewowicki, 1992, s. 122): „Trudności i niedoskonałości zgłębiania złożonych spraw aksjologii, indywidualnych i społecznych celów życiowych i motywacji, obrazu i uwarunkowań dążeń - i wielu innych zagadnień dotyczących świata idei i wartości oraz zachowań człowieka - nie odwodzą jednak (i słusznie) ani profesjonalnych badaczy, ani też ludzi pozazawodowo zainteresowanych wspomnianymi kwestiami od prób poznawania tego, co wyznacza sens życia, dążenia i postępowania człowieka (jednostki, małych i dużych grup) (Lewowicki, 1992, s. 122)". O realizacji celów na lekcji decyduje nauczyciel. To on swoją postawą przekazuje najważniejsze hierarchie wartości ${ }^{8} \mathrm{i}$ realizuje je w procesie dydaktycznym.

Pozostając na zasygnalizowaniu nierozwiązalności spraw związanych ze zrozumieniem nasycenia aksjologicznego pojęć dotyczących zarówno tożsamości, jak i więzi społecznych, przyjrzyjmy się hierarchiom wskazywanym przez nauczycieli.

Pytanie o preferowane hierarchie wartości w szkole na pograniczach dotyczy różnych kulturowo szkół: Czy nauczyciele szkół dla mniejszości i szkół dla większości postrzegają realizowane hierarchie wartości w szkole w ten sam sposób? W artykule wyszczególnione zostały - wskazywane ze względu na ich ważność - wartości ${ }^{9}$ : godność, wolność, sprawiedliwość, szacunek, zaufanie, odpowiedzialność i tolerancja. Do wyznaczenia hierarchii została dodana wartość wymieniana w pedagogice - samorealizacja. Jest to wartość niewątpliwie zobowiązująca do oddziaływań pedagogicznych, tj. wspomagania jej odkrywania, bowiem - jak już wskazano (za: Lewowicki, 1993) właśnie w typowych "humanistycznych” ujęciach pojęcie „ja” bywa traktowane jako symbol samookreślenia i samorealizacji. W ujęciach filozoficznych ujmuje się także tożsamość jako należącą do sfery samorealizacji człowieka (Dybel i Wróbel, 2008, ss. 186-187), a zatem tak sformułowane zadanie pedagogiki wytycza jej wymogi aksjologiczne (Górniewicz, 1997, s. 59).

Sformułowane zostało pytanie, jak w poszczególnych krajach, a także w zależności od szkoły mniejszości-większości widzą nauczyciele cele i zadania szkoły w zakresie wdrażania wartości i przygotowania do ich realizacji. Ustanowione w zakresie Spraw tożsamości i więzi społecznych ${ }^{10}$ hierarchie - przy wymienianiu tak istotnych wartości - miały na celu wyłonienie najważniej-

8 Przyjmując definicję postawy za Florianem Znanieckim (,jednostkowy przeciwczłon wartości społecznej”), jak cytuje Stefan Nowak (Nowak, 1973, s. 22).

9 Wprowadzone skrótowo w artykule, a rozwinięte w części teoretycznej przywoływanej rozprawy autorki (Urban, 2014a).

10 Określane hierarchie ujmują (patrz tabela 1) wartości: godność - tolerancja wolność - odpowiedzialność - sprawiedliwość - zaufanie - szacunek - samorealizacja. 
szych i specyficznych zgodności i „odstępstw” - zarówno w obrębie szkół dla mniejszości oraz w obrębie szkół dla większości, jak i dla szkól w obrębie poszczególnych środowisk (państw).

W niniejszym artykule na podstawie uzyskanych wyników (tabela 1) należy zauważyć wartości o najwyższych uzyskanych rangach i w tym kontekście spodziewaną jako najważniejszą w szkole „samorealizację” jako wartość uzyskującą w rangowaniu najniższą pozycję. W dalszym ciągu wskazane są najważniejsze zgodności i rozbieżności według państw, tj. szkół mniejszości i większości z tych samych środowisk, by na tym tle zobaczyć/podkreślić zgodne najniższe usytuowanie samorealizacji w ustanawianych hierarchiach.

Pierwsze miejsce w szkołach dla mniejszości (w Polsce szkoły z klasami dla mniejszości) zajmują: w Polsce - godność, wolność, odpowiedzialność, sprawiedliwość i szacunek; w Czechach - odpowiedzialność, sprawiedliwość i zaufanie; na Słowacji - wolność; na Węgrzech - tolerancja. Pierwsze miejsce w szkołach dla większości zajmują: w Polsce - tolerancja; w Czechach odpowiedzialność; na Słowacji - godność; na Węgrzech wolność i tolerancja.

Tabela 1. Hierarchia realizowanych w szkole wartości Spraw tożsamości $i$ więzi społecznych w ocenach nauczycieli ze szkół dla mniejszości i szkół dla większości

\begin{tabular}{|l|c|c|c|c|c|c|c|c|}
\hline \multirow{2}{*}{$\begin{array}{l}\text { Wartości hierarchii: Spraw tożsamo- } \\
\text { sięzi spotecznych }\end{array}$} & \multicolumn{4}{|c|}{ M } & \multicolumn{4}{|c|}{ W } \\
\cline { 2 - 10 } & PL & CZ & SK & HU & PL & CZ & SK & HU \\
\hline A - godność & 1 & 5 & 6 & 8 & 4 & 4 & 1 & 3 \\
\hline B - tolerancja & 6 & 7 & 5 & 1 & 1 & 3 & 3 & 1 \\
\hline C - wolność & 1 & 5 & 1 & 3 & 7 & 2 & 2 & 1 \\
\hline D - odpowiedzialność & 1 & 1 & 3 & 2 & 3 & 1 & 5 & 4 \\
\hline E - sprawiedliwość & 1 & 1 & 2 & 4 & 4 & 4 & 4 & 5 \\
\hline F - zaufanie & 7 & 1 & 4 & 5 & 4 & 8 & 5 & 7 \\
\hline G - szacunek & 1 & 4 & 7 & 6 & 2 & 6 & 7 & 5 \\
\hline H - samorealizacja & 8 & 8 & 8 & 7 & 8 & 7 & 8 & 8 \\
\hline
\end{tabular}

Legenda: W tabeli podane są rangi przyznane przez nauczycieli dla wymienionych w tabeli wartości nazwanych hierarchią Spraw tożsamości i więzi społecznych. Miejsce w hierarchii dla wymienionych wartości określane jest osobno w szkołach $\mathrm{M}(\mathrm{W})$ licea ogólnokształcące z wykładowym językiem nauczania mniejszości (większości), a w kolumnach wskazane są rangi przyznane przez nauczycieli: PL - licea w Polsce; CZ - licea (gimnazja*) w Republice Czeskiej; SK - licea (gimnazja*) na Słowacji; HU - licea (gimnazja*) na Węgrzech; " gimnazjum w CZ, SK, HU to odpowiednik liceum w PL. Określane przez nauczycieli hierarchie dla realizacji wartości w szkołach w badaniach (patrz przypis 37 ) ujęte były porównawczo jako rangi przyznawane dla lat 2004 i 2010, a chociaż średnie ocen nieznacznie się różnią, to uzyskane rangi ocen dla tych lat są takie same. W niniejszym artykule rangi dotyczą ocen nauczycieli dla roku 2010 (dla roku 2004 opracowanie w: Urban, 2014a, ss. 460-467). 
W szkołach dla mniejszości zasługuje na uwagę duże zróżnicowanie usytuowania w hierarchiach godności (PL - 1; $\mathrm{HU}-8)$, tolerancji ( $\mathrm{HU}-1$; PL/ $\mathrm{CZ}-6 / 7)$, zaufania $(\mathrm{CZ}-1$; PL - 7) i szacunku (PL - 1; SK - 7) w hierarchiach zadań szkoły w opiniach nauczycieli. W szkołach dla większości tego typu różnice dotyczą wolności (PL - 7; HU - 1).

Zgodność w szkołach mniejszości i większości według krajów pokazuje inną perspektywę: w Czechach odpowiedzialność (M/W: 1/1), w Polsce szacunek (M/W: 1/2), na Słowacji wolność (M/W: 1/2), na Węgrzech tolerancję (M/W: 1/1).

Należy jednak podkreślić zgodność zadziwiającą, bo dotyczącą preferencji szkoły - umieszczanie w obydwu typach szkół i we wszystkich środowiskach na końcu samorealizacji, wartości z punktu widzenia zadań szkoły w stosunku do ucznia najważniejszej. Samorealizacja jest konsekwentnie umieszczana na ostatnich miejscach (7-8) we wszystkich grupach.

Powtórzmy, obowiązująca w obszarze naszej cywilizacji zasada, że „wartości świata należy odliczać, zaczynając od jednostki ludzkiej” (Obuchowski, 1993, s. 9), formułuje zadania szkoły jako przygotowanie uczniów do samorealizacji - zasady podmiotowego standardu ewaluacji (Obuchowski, 1993, s. 9): siebie jako źródła swego postępowania; celów jako przedmiotu swoich intencji; świata jako szansy swoich możliwości. Postulat ten zgodny jest z zadaniami szkoły rozumianej jako organizacja powołana do realizowania określonych dla niej celów, ma ona wspomagać wydobycie specyfiki tkwiącej w podmiocie (Drucker 1999, s. 164).

\section{Uwagi końcowe}

W kontekście samorealizacji rozważa się problematykę statusów i związanych z nimi "szans życiowych", a to także sprawa rozumienia „jakości życia”. W definicjach „jakości życia” wyróżnia się grupę definicji, uwzględniającą podmiotowe potrzeby (szczególnie te wyższego rzędu związane np. z samorealizacją czy stopniem satysfakcji z życia kulturalnego), wprowadzając ponadto koncepcje subiektywnej bądź też „postrzeganej” jakości życia (Trzebiatowski, 2011, ss. 28-29).

W Europejskich Ramach Odniesienia wymienia się osiem dziedzin kompetencji kluczowych (Rabczuk, 2012, s. 352), których rozwijanie traktuje się jako niezbędne, jako ogół podlegających „transferowi i wielofunkcyjnej wiedzy, umiejętności i postaw niezbędnych każdej jednostce do jej samorealizacji i rozwoju osobistego, integracji społecznej oraz życia zawodowego" 
(Rabczuk, 2012, s. 352), a które można charakteryzować jako zgodne z postulatami edukacji dla zrównoważonego rozwoju (Urban, 2014b).

Tadeusz Lewowicki podkreśla samorealizację w kontekście aksjologicznym: „W spojrzeniu na sferę publiczną i jej moralność właściwe wydaje się nawiązanie do (...) ponadczasowych, uniwersalnych wartości - takich jak m.in. wolność, pokój, prawo do (godnego) życia, demokracja, podmiotowość i tożsamość człowieka, pluralizm polityczny i światopoglądowy, tolerancja, godziwy poziom życia duchowego i materialnego, rodzina, edukacja, praca, możliwość samorealizacji. (...) Przywołane wartości dobrze jednak ilustrują to, że nadrzędną wartością w ujęciu współczesnej aksjologii jest w istocie człowiek, jego życie, rozwój, wolność, samorealizacja” (Lewowicki, 2007, s. 38). Zaś kontekście samorealizacji formułuje także zadania szkoły: „Szkoła (i cały system edukacji) służyć mają przede wszystkim obywatelom, sprzyjać (...) ich rozwojowi, wspomagać procesy samorealizacji, oferować światy wartości, wiedzę i sprawności pomagające w dokonywaniu wyborów dróg życiowych (m.in. zawodowych, rodzinnych, obywatelskich)" (Lewowicki, 2007, s. 38).

\section{Bibliografia}

Baranowski, M. 2009. Apropriacja szans życiowych w kapitalizmie informacyjnym. W: Podemski, K. red. Spór o społeczne znaczenie społecznych nierówności. Poznań: UAM, ss. 135-148.

Bunikowski, D. 2006. Podstawy aksjologiczne Konstytucji dla Europy. www. racjonalista.pl/kk.php/s,4576, (25.02.2011).

Domański, H. 2004. Struktura społeczna. Warszawa: Wydawnictwo Naukowe Scholar.

Drucker, P. F. 1999. Społeczeństwo pokapitalistyczne. Warszawa: Wydawnictwo Naukowe PWN.

Dybel, P. i Wróbel, S. 2008. Granice polityczności: od polityki emancypacji do polityki życia. Warszawa: Instytut Filozofii i Socjologii Polskiej Akademii Nauk, Fundacja Aletheia,

Giddens, A. 2009. Europa w epoce globalnej. Warszawa: Wydawnictwo Naukowe PWN.

Górniewicz, J. 1997. Kategorie pedagogiczne. Odpowiedzialność, podmiotowość, samorealizacja, tolerancja, twórczość, wyobraźnia. Olsztyn: Wyższa Szkoła Pedagogiczna. 
Kotarbiński, T. 1993. Etyka i pedagogika. W: Pomykało, W. red. Encyklopedia pedagogiczna. Warszawa: Fundacja Innowacja, ss. 199-200.

Lewowicki, T. 1992. Drugi szkic do charakterystyki dzieci z Zaolzia. W: Lewowicki, T. red. Hierarchia wartości i plany życiowe dzieci z Zaolzia. Cieszyn: UŚ - Filia w Cieszynie, ss. 122-135.

Lewowicki, T. 1993. Podmiotowość w edukacji. W: Pomykało, W. red. Encyklopedia pedagogiczna. Warszawa: Fundacja Innowacja, ss. 592-600.

Lewowicki, T. 2007. Pedagogika wobec (nie)moralności sfery publicznej. W: Rutkowiak, J., Kubinowski, D., Nowak, M. red. Edukacja - moralność - sfera publiczna: materiaty z VI Ogólnopolskiego Zjazdu Pedagogicznego PTP. Lublin: Oficyna Wydawnicza „Verba”, ss. 34-51.

Mariański, J. 2016. Godność ludzka jako wartość społeczno-moralna: mit czy rzeczywistość? Studium interdyscyplinarne. Toruń: Wydawnictwo Adam Marszałek.

Nowak, M. 2009. Pedagogika personalizmu a tożsamość szkoły. W: Chałas K. red. Kreowanie tożsamości szkoty. Konteksty teoretyczne, poglady, wyniki badań. T. 1. Lublin: KUL, ss. 32-43.

Nowak, S. 1973. Pojęcie postawy w teoriach i stosowanych badaniach społecznych. W: Nowak, S. red. Teorie postaw. Warszawa 1973, PWN, ss. 21-44.

Obuchowski, K. 1993. Człowiek intencjonalny. Warszawa: Wydawnictwo Naukowe PWN.

Olbrycht, K. 2003. Rola kształcenia aksjologicznego w działaniach pedagogicznych w społecznościach wielokulturowych. W: Lewowicki, T., Ogrodzka-Mazur, E. i Gajdzica, A. red. Świat wartości i edukacja międzykulturowa. Cieszyn - Warszawa: UŚ - Filia w Cieszynie, Wyższa Szkoła Pedagogiczna ZNP w Warszawie, ss. 212-219.

Poleszczuk, J. 2002. Czym jest społeczeństwo? W: Marody, M. red. Wymiary życia spotecznego. Polska na przełomie XX i XXI wieku. Warszawa: Wydawnictwo Naukowe Scholar, ss. 14-24.

Preuss-Kuchta, L. 2009. Oswajanie pedagogiki jako jeden z warunków konstytuowania się tożsamości szkoły. W: Chałas, K. red. Kreowanie tożsamości szkoły. Konteksty teoretyczne, poglady, wyniki badań. T. 1. Lublin: KUL, ss. 18-24.

Rabczuk, W. 2012. Kompetencje kluczowe i ich komponent międzykulturowy. W: Szczurek-Boruta, A. i Ogrodzka-Mazur, E. red. Poza paradygmaty. Pedagogika międzykulturowa. Ksiega pamiatkowa dedykowana Profesorowi Tadeuszowi Lewowickiemu. T. 2. Toruń: Wydawnictwo Adam Marszałek, ss. 345-356. 
Sitek, M. 2009. Europeizacja edukacji i przez edukację. W: Kurczewska, J. i Bojar, H. red. Wyciskanie Brukselki? O europeizacji społeczności lokalnych na pograniczach. Warszawa: Wydawnictwo Instytutu Filozofii i Socjologii PAN, ss. 274-275.

Szacki, J. 2004. Czy istnieje socjologia narodu? W: Gorlach, K., Niezgoda, M. i Seręga, Z. red. Wtadza, naród, tożsamość. Studia dedykowane Profesorowi Hieronimowi Kubiakowi. Kraków: UJ, ss. 53-62.

Śliwerski, B. 2013 Diagnoza uspołecznienia publicznego szkolnictwa III RP w gorsecie centralizmu. Kraków: Oficyna Wydawnicza „Impuls”.

Trzebiatowski, J. 2011. Jakość życia w perspektywie nauk społecznych i medycznych - systematyzacja ujęć definicyjnych. Hygeia Public Health. 46 (1), ss. 25-31.

Urban, J. 2014a. Mniejszości narodowe krajów Grupy Wyszehradzkiej w procesach integracyjnych Europy - tożsamość młodzieży mniejszości autochtonicznych. Torun: Wydawnictwo Adam Marszałek.

Urban, J. 2014b. Rok ważnych Jubileuszy - o czym przypominają edukacji? Oświatologia/Освітологія. Polsko-ukraiński rocznik. 3, ss. 105-108.

\title{
Significance of self-fulfilment in the system of values preferred at school in the opinions of teachers from schools for minorities and majorities in the multicultural environments of Visegrad Group countries
}

\begin{abstract}
Contemporary societies assign an important place to the value of selfrealization. Regardless what has been stated, it is important to place self-realization in the system of values. In the article the place of self-realization in the system of values in school reality is considered. Assuming that school as an educational institution shapes the process of creating student's identity and the way the student perceives social world, the system of values which is transferred there and the place of self-realization in this hierarchy are essential.

The article presents system of values in the opinions of teachers from uppersecondary schools for minorities and majorities from multicultural environments in Visegrad countries. The environments include: German minority in Poland, Polish minority in Czech Republic, Hungarian minority in Slovakia and Slovak minority in Hungary. The hierarchies determined by the teachers concern identity and social bonds. The values included in the hierarchy are: dignity - tolerance freedom - responsibility - justice - trust - respect - self-realization.
\end{abstract}


The article shows teachers opinions concerning the place of dignity in the system of values at schools. It has been found that the place accorded to dignity among values varies, depending on country and whether the school is for minority or majority. The place of other values in the hierarchy is also presented, depending on the kind of school and country. Unfortunetly the last place in system of values takes self-realization.

Keywords: self-fulfilment, system of values, school in borderlands

Translated by Janina Urban 